The research program of the Center for Economic Studies (CES) produces a wide range of theoretical and empirical economic analyses that serve to improve the statistical programs of the U.S. Bureau of the Census. Many of these analyses take the form of CES research papers. The papers are intended to make the results of CES research available to economists and other interested parties in order to encourage discussion and obtain suggestions for revision before publication. The papers are unofficial and have not undergone the review accorded official Census Bureau publications. The opinions and conclusions expressed in the papers are those of the authors and do not necessarily represent those of the U.S. Bureau of the Census. Republication in whole or part must be cleared with the authors.

\title{
USING INTERNAL CURRENT POPULATION SURVEY DATA TO REEVALUATE TRENDS IN LABOR EARNINGS GAPS BY GENDER, RACE AND EDUCATION LEVEL
}

\author{
by
}

Richard V. Burkhauser *
Cornell University

and

Jeff Larrimore *

Cornell University

CES 08-18 July, 2008

All papers are screened to ensure that they do not disclose confidential information. Persons who wish to obtain a copy of the paper, submit comments about the paper, or obtain general information about the series should contact Sang V. Nguyen, Editor, Discussion Papers, Center for Economic Studies, Bureau of the Census, 4600 Silver Hill Road, 2K132F, Washington, DC 20233, (301-763-1882) or INTERNET address sang.v.nguyen@census.gov. 


\begin{abstract}
Most empirical studies of trends in labor earnings gaps by gender, race or education level are based on data from the public use March Current Population Survey (CPS). Using the internal March CPS, we show that inconsistent topcoding in the public use data will understate these gaps and inaccurately capture their trends. We create a cell mean series beginning in 1975 that provides the mean of all values above the topcode for each income source in the public use March CPS and better approximate earnings gaps found in the internal March CPS than was previously possible using publically available data.
\end{abstract}

* The research in this paper was conducted while the authors were Special Sworn Status researchers of the U.S. Census Bureau at the New York Census Research Data Center at Cornell University. The paper was completed while Burkhauser was a Visiting Scholar at the American Enterprise Institute. Research results and conclusions expressed are those of the authors and do not necessarily reflect the views of the U. S. Census Bureau. This paper has been screened to ensure that no confidential data are disclosed. Support for this research came from the National Science Foundation (award nos. SES-0427889 SES-0322902, and SES-0339191) and the National Institute for Disability and Rehabilitation Research (H133B040013 and H133B031111). We thank Lisa Marie Dragoset, Arnie Reznek, Laura Zayatz, the Cornell Census RDC Administrators, and all their U.S. Census Bureau colleagues who have helped with this project. 


\section{Introduction}

The March Current Population Survey (CPS) is a large, nationally representative sample of households collected each March since 1942 by the U.S. Census Bureau. ${ }^{1}$ The public use version of the March CPS is the primary data source used to investigate yearly trends in United States average labor earnings and its distribution. However, to protect the confidentiality of its respondents, the Census Bureau topcodes the highest values from each source of income that it collects when it reports them in the public use March CPS data. One of the challenges this presents for those using the public use March CPS to examine labor earnings levels and trends over time is that these topcodes are time-inconsistent, leading to artificial increases or decreases in earnings at the top of the income distribution as different fractions of the population are subject to topcoding each year. See Levy and Murnane (1992) for an early review of this problem in the earnings inequality literature. For a more recent discussion, see: Feng, Burkhauser, and Butler (2006). While the public use March CPS is used extensively to measure female-male and black-white earnings gaps (see, among others, Juhn, et al. 1991; Blau and Kahn 2000; Card and Dinardo 2002; Couch and Daly 2002; Juhn 2003), little is known about how topcoding impacts comparisons of labor earnings across these subsets of the population. ${ }^{2}$

In this paper we show that levels and trends in the female-male, black-white, and various education level ratios in labor earnings, or the earnings gaps between these groups, are sensitive to topcoding by comparing their values using alternative methods of controlling for topcoding in the public use March CPS to values found using the internal March CPS data between 1975 and 2006.

We find that the earnings gaps calculated using our extended cell mean series in conjunction with public use March CPS data closely approximate those obtained with the Census 
Bureau's internal CPS data. Additionally, we find that women, blacks, and the less-educated are relatively worse off compared to men, whites, and the more-educated than previously seen using the public use CPS data. We also show that the time-trends for each of these earnings gaps are sensitive to topcoding, although the impact of topcoding corrections on trends differs based on the years examined.

\section{Calculating the Earnings Gaps by Gender, Race, and Education Level}

To calculate earnings gaps, we examine the annual labor earnings from wages, selfemployment, and farm income of full-time, full-year workers in the March CPS. ${ }^{3}$ Prior to 1987 these income sources are reported as three separate values. Since then a fourth source—primary labor income (regardless of source) has been added. The income sources and their names in the public and internal March CPS data files are listed in Appendix Table 1. Much of the previous work exploring earnings gaps by gender, race, or education level focuses solely on wage income and excludes self-employment and farm income, primarily because of concerns about the accuracy of self-employment income in the March CPS. However, as Devine (1994) demonstrates self-employment income is relevant to earnings gaps, since the gender earnings gap is larger among full-time self employed workers than among full-time wage earners. Since we are interested in comparisons of the full level of financial resources that individuals are generating for their households through their labor market work, we include all labor earnings in our analysis - including those from farm and self-employment.

An additional measurement detail is whether to analyze annual earnings or whether to rescale the results to use weekly or hourly wages instead. While we use annual earnings, this choice should not greatly influence the results. However, since women tend to work fewer 
weeks per year, using a weekly or hourly measure does generate a slightly smaller gender earnings gap (Blau and Kahn 2000).

A third measurement question is how best to calculate group earnings when calculating earnings gaps. To limit the impact of outliers on the female-male earnings gap, the Census Bureau uses median rather than mean earnings when reporting the gender earnings gap in their Income, Poverty, and Health Insurance Coverage in the United States series (U.S. Census Bureau, 2007a). The Census Bureau does not calculate earnings gaps by race or education in this report. The gender gap in median earnings presented by the Census Bureau is regularly reproduced in fact sheets by policy institutes (National Women's Law Center 2006; Institute for Women's Policy Research 2008) and has been widely presented as background information in the literature on the gender pay gap (Blau and Kahn 2000; O’Neill 2003). However, using median earnings comes at the cost of only using a single point in the income distribution. As a result, if women made substantial gains compared to men at either tail of the distribution, a simple comparison of the median over time would miss these gains that do not occur around the midpoint of the distribution. Since our focus is on the upper tail of the distribution where most topcoding occurs, we instead evaluate mean earnings, which will better reflect changes occurring throughout the entire earnings distribution.

Despite these differences in calculating the earnings gaps, the general trends in the earnings gap in the literature have generally been consistent. Most previous literature has found that the gender earnings gap was largely unchanged for much of the $20^{\text {th }}$ Century until the 1980 s, at which point women made substantial gains. In the 1990s, however, these gains subsided and the gap in earnings between women and men was stable for much of the decade (Blau and Kahn 1997; Blau and Kahn 2000; Card and DiNardo 2002; O’Neill 2003). 
While the consensus opinion is that the black-white earnings gap has also been shrinking, the timing of its decline differs greatly from that observed for the female-male earnings gap. The black-white earnings gap declined rapidly from World War II until the middle of the 1970s before stagnating or increasing slightly through much of the 1980s (Juhn, et al. 1991; Bound and Freeman 1992; Card and Dinardo 2002; Couch and Daly 2002, Juhn 2003). In the 1990s, there is some disagreement on the direction of the black-white earnings gap, with Card and Dinardo (2002) finding the gap more or less constant while Couch and Daly (2002) and Juhn (2003) saw a return to a declining earnings gap. Below we show the sensitivity of these kinds of earnings trends to alternative methods of controlling for topcodes in the March CPS.

\section{Topcoding in the March CPS}

To protect the confidentiality of respondents, the Census Bureau topcodes each source of income respondents report in the public use March CPS survey. The full list of topcode values over time is presented in Appendix Tables 2 and 3. In addition to topcoding each income source in the main income supplement, the Census Bureau topcodes the usual weekly earnings in the Outgoing Rotation Group survey, preventing researchers from obtaining additional income information from other questions in the CPS surveys. Because these topcodes are time inconsistent they can impact both the level of the earnings gap and it trends over time.

In income year 1995 the Census Bureau began providing cell means for topcoded individuals in the public use March CPS - the mean income of all individuals who are topcoded from that topcoded source of income. Prior to 1995, the Census Bureau simply replaced the incomes of topcoded individuals with the topcode value. Since cell means were not provided 
retroactively in years prior to 1995, using the public use March CPS data without taking this major change in reported income values into account results in a sizable increase in 1996 and beyond in their measured income due to more accurate reporting of their incomes since then. Hence, while the use of cell means after 1995 causes the public use March CPS to conform better to the internal March CPS, not taking this improvement in measurement into account will grossly overestimate actual increases in labor earnings after 1995 compared to prior years. (See Feng, Burkhauser, and Butler, 2006).

Topcoding has important implications for measuring the relative labor earnings, or earnings gap, of different subsamples of the population. For example, if the distribution of labor earnings of women and men were identical, individuals in both groups will be topcoded at the same rate. So, topcoding would reduce the mean incomes of both men and women by the same percentage, leaving intergroup inequality unchanged.

However, if individuals in the two groups have different probabilities of being topcoded or if the mean suppressed labor earnings of those who are topcoded differ between the two groups, topcoding will influence the earnings gap measure. If women are concentrated at lower earnings levels where they are less likely to be topcoded, we would expect topcoding to artificially raise the ratio of their mean earnings relative to men, because their observed mean earnings will be less artificially depressed from the topcodes than that of men and hence will be closer to their true mean. Similar results will occur even if the probability of topcoding is the same across both groups if the amount of suppressed earnings is higher for men than for women. Under these circumstances, we would find an artificial increase in the earnings gap between women and men resulting from the topcodes. 


\section{Prevalence of Topcoding by Gender, Race and Education Level}

Table 1 shows the percentage of full time, full year workers in the public use March CPS topcoded for one or more sources of labor income. While its prevalence varies substantially across our gender, race, and education level groups, as can be seen in Table 1 topcoding is not only found but has increased substantially over the past 30 years for each group. For example, virtually no women (column 1) or black (column 4) full-time and full-year workers had topcoded labor earnings in 1975, but almost 1 percent of each had such topcodes in 2006.

While topcoding has been rising among all gender, race and education level groups, in any given year there are substantial differences in topcoding rates between these groups. Women are less likely to be topcoded than men (column 2). So, we expect differences between their observed and true mean labor earnings will be greater. Hence correcting for topcoding will show that women's labor earnings relative to men's are lower than previously reported.

Similarly, as can be seen in Table 1, topcoding is much less prevalent among blacks than whites (5). So, we expect differences between their observed and true mean labor earnings will be greater. Hence correcting for topcoding will show that blacks' labor earnings are relatively lower compared to whites’ than previously reported.

Finally, as can be seen in Table 1 when exploring the returns to education by comparing those with at least some college education (9) to those with only a high school degree (8) or less (7), a greater portion of those with some higher education are topcoded. So, we expect differences between their observed and true mean labor earnings will be greater. Hence correcting for topcoding will show that the labor earnings of those with a high school degree or less are relatively lower than previously reported. 
As can be seen in columns (3), (6), (10) and (11), the relative ratios of topcoding have also changed over time. In 2006, women were topcoded 35 percent as much as men,, up from only 2 percent as much in 1975. In 2006, blacks were topcoded 39 percent as much as whites, compared with 1975 when no blacks were topcoded. And it is also the case that the lesseducated are topcoded at higher rates compared to the more-educated in 2006 than they were in 1975. Hence earnings gaps trends by gender, race and education level are also likely to be affected by topcoding.

\section{Methods to Correct for Topcoding Problems}

Topcoding in the public use March CPS data can be controlled in various ways. A first approach (Unadjusted Public Use) is to just use the unadjusted public use March CPS data as released by the Census Bureau. However, as discussed above, this will result in a series whose labor earnings levels are suppressed prior to 1995, due to topcoding, mixed with much higher earnings levels thereafter due, to some degree, to the Census Bureau's introduction of cell means in 1995. This shift to cell means in 1995 is further complicated by changes to the topcode level made by the Census Bureau at the same time. For instance, the topcode for primary earnings income rose from $\$ 99,999$ to $\$ 150,000$ thus reducing the share of full-time male workers who were topcoded on their own primary labor earnings from 3.93 to 1.35 percent, but the use of cell means increased the average reported primary labor earnings of those men who were still topcoded to $\$ 305,989$.

A second approach (No Cell Mean Public Use) is to simply ignore the introduction of cell means into the public use March CPS, and produce a labor earnings series where all topcoded values are assigned a value at the topcode level even after the introduction of cell means in 1995. 
While this will remove the large artificial jump in labor earnings due to the introduction of cell means in 1995, it does not address the basic problems of inconsistent topcode level changes over time (such as the change in primary labor earnings topcoding from $\$ 99,999$ to $\$ 150,000$ between 1994 and 1995) or the different topcoding rates across subgroups of the population. ${ }^{4}$

A third approach (Consistent Top Coded Public Use) is to create a consistent topcoded series. (See: Burkhauser, Butler, Feng, and Houtenville, 2004, for labor earnings and Burkhauser, Couch, Houtenville and Rovba, 2005, for household income.) For each income source, this series takes the topcode that cuts most deeply into that source's income distribution in a given year and then chooses a topcode value that cuts that deeply into that source's income distribution in all other years. This approach is preferable to either the Unadjusted Public Use data or the No Cell Public Use means data in that it consistently measures a given percentage of the income distribution of that income source in all years of the study. However, this timeconsistency in topcode rates comes at the cost of losing information by topcoding a larger fraction of the population in all other years. In our case, where we are looking at labor earnings for full-time, full-year workers, the cut into the data using consistent topcoding ranges from 2.5 to 3.8 pecent. This compares to topcoding in the public use March CPS on all income sources for all individuals that ranges from 0.6 to 2.7 percent depending on the year.

Just as the existence of topcoding in the public use March CPS data can distort the levels and trends in earnings inequality across groups, increasing the fraction of the population who are topcoded can exacerbate the problem. Because more individuals are topcoded with this approach than in the public data, the observed mean labor earnings of each subgroup in the population will be lower. But, because most of the people who are captured by our reduction in the topcodes are men, white or more educated, using this approach will reduce their mean income more than it 
will the mean labor earnings of women, blacks or the less educated. Hence we will consistently overestimate the mean income of workers with the former set of characteristics relative to workers with the latter characteristics by disproportionately excluding the top part of the labor earnings distribution.

Given the limitations of consistent topcoding in providing a consistent comparison of the economic well-being of subpopulations, we provide a new method for controlling for topcoding in the public use March CPS data. Using the internal March CPS data, we use approximately the same methodology the Census Bureau used to create its cell means after 1995 and extend the series back to 1975 . With our cell means, which are now publicly available in Larrimore, Burkhauser, Feng, and Zayatz (2008), it is possible to create a consistent cell mean series that can be used with the public use March CPS, which better matches the income distributions found in the internal March CPS data for each of the population subgroups that we examine. ${ }^{5}$

While our cell mean approach has significant advantages over consistent topcoding because it allows us to better understand changes at the top of the income distribution, it does not capture the full distribution. In addition to topcoding income in the public use March CPS data, the Census Bureau censors high income values for each source of income in the internal March CPS data (See Welniak, 2003, Feng et al. 2006, and Burkhauser et al. 2007 for a fuller discussion). The full list of internal censoring points is reported in Appendix Tables 2 and 3. Since the internal March CPS data is censored, values at the very top of the distribution for each source of income will not be observed in these data. This poses a potential problem in creating a cell mean series for the public use March CPS from the internal March CPS data since at best it will match the trends found in the internal data from which the cell means are created. If changes 
in the censoring points in the internal March CPS data result in inconsistencies, our cell mean series used with the public use March CPS data will retain those inconsistencies.

While this is a limitation of our cell mean series in measuring the "true" trends in labor earnings, the problem is mitigated because censoring points in the internal March CPS data are more stable than their public use March CPS counterparts. Since the Census Bureau switched from reporting three sources of labor earnings to four sources in 1987, the only changes in the internal March CPS censor levels occurred in 1992 and 1993. As a result, while there is a disconnect in the internal March CPS between these years, using our cell means with the public use March CPS allows for consistent trends before and after these years that closely match the internal March CPS data.

Additionally, since the censoring points in the internal March CPS data are much higher than the topcodes in the public use March CPS data, the fraction of individuals who are impacted by them is lower than the fraction impacted by the public use March CPS topcodes. Thus, while some censoring does occur in the internal March CPS data, the results we provide using the extended cell mean series with the public use March CPS data (Cell Means Public Use) are much closer to results that would be obtained using data that consistently captured the full income distribution. The additional information gained by using our cell means series with the public use March CPS justifies using the extended cell mean series despite the cost of accepting a trendbreak in 1993 in our analysis.

\section{Comparison of Mean labor earnings by Gender, Race, and Education Level}

In Table 2 we compare the mean labor earnings of men and women who work full-time and full-year from 1975-2006 using our extended cell mean series together with the public use 
March CPS data (Cell Mean Public Use) to those using the unadjusted public use March CPS data (Unadjusted Public Use), the public use March CPS data without cell means (No Cell Mean Public Use), the public use March CPS data consistently topcoded (Consistent Topcode Public Use), and the internal March CPS data used by the Census Bureau (Internal). For each series, the first column presents the mean labor earnings of women and the second column presents the mean labor earnings of men. The third column is the ratio of these two values. It measures the average economic well-being of women who work full-time and full-year relative to full-time, full-year male workers.

Thanks to Census Bureau provided cell means, the mean income of full-time, full-year male and female workers captured in the Unadjusted Public Use data since 1995 is very close to our Cell Mean Public Use means and both are very close to the mean values in the 2004 Internal data. So for those simply interested in comparing the relative income of those with and without work limitations in years since 1995 when cell means were first provided by the Census Bureau, the current Unadjusted Public Use data or our Cell Mean Public Use data nicely capture the mean earnings in the Internal data.

But for those interested in these series prior to 1995 the Unadjusted Public Use data is flawed because it does not provide cell means for persons above the topcoded values. Hence its mean values are smaller for both men and women. In contrast, our Cell Mean Public Use data provide yearly means very close to those from the Internal data for both men and women.

Because the Unadjusted Public Use series consistently understates the labor earnings of both men and women, the ratio of these two values could in principal be greater or less than the ratio in the Cell Mean Public Use and Internal series. But as we have shown in Table 1, men are more likely than women to be topcoded so their amount of suppressed labor earnings from 
topcoding is likely to be greater. We therefore expect the ratio to be higher in the Unadjusted Public Use series than in the Cell Mean Public Use and Internal series in the years where cell means were not calculated. This is the case, as can be seen by comparing the ratios for 19751994 in the three series. In 1990, for example, the Unadjusted Public Use series ratio is 0.677, greater than 0.655 and 0.654 in the other two series. Since the Unadjusted Public Use series uses different topcoding adjustments before and after 1995, most yearly comparisons of before-1995 years to after-1995 years using this data series will show a greater decline in the relative labor earnings of women after 1995 than when using the more accurate Cell Means Public Use series.

In contrast to these three series, both the No Cell Mean Public Use and the Consistent Topcode Public Use series understate the mean earnings of both men and women in all years. As predicted both series miss less of the labor earnings of men than women, so their female-male earnings ratios are always above those of our Cell Mean Public Use series and the Internal series. Finally, in 2006, researchers using the Consistent Topcoding Public Use series to calculate the gender earnings gap will understate the size of the earnings gap by over 4.3 percentage points relative to the Cell Mean Public Use and Internal series.

In Table 3, we provide a similar analysis comparing the labor earnings of blacks and whites under each of the four methods of controlling for topcoding. As was the case when examining how labor earnings differ between women and men, for researchers only interested in the relative labor earnings of blacks and whites since 1995 when the Census Bureau first provided cell means, using the Unadjusted Public Use series very closely approximate the mean earnings levels observed in the Cell Mean Public Use or Internal data. However, for researchers interested in earnings ratios prior to 1995, because whites are more likely to be topcoded the Unadjusted Public Use data will understate the mean earnings of white workers by a greater 
percentage than it understates the mean earnings of black workers. As a result, prior to 1995 black workers appear comparatively better off than they actually are. Thus, when examining trends over time using the Unadjusted Public data, one will observe a dramatic artificial decline in the economic well being of black workers in 1995.

While the No Cell Mean Public Use data and Consistent Topcode Public Use series avoid this large artificial increase in the earnings gap between black and white workers in 1995, they also understate the earnings gap in each year since 1975. In contrast to these series which consistently understate the earnings of both races and overstate the relative earnings of black workers, the Cell Means Public Use series closely replicates the mean earnings levels of both races seen in the Internal data.

It should not come as a great surprise that the Cell Mean Public Use series based on our cell means used in conjunction with the public use March CPS is able to replicate the results from Internal data for comparisons across race and genders, since race and gender were two of the conditioning criterion used when generating the cell means for each income source. Thus, a natural question is whether our Cell Mean Public Use series is as successful at replicating the labor earnings obtained using Internal data for subsets of the population that do not match its conditioning criteria.

In Table 4 we compare labor earnings across different education levels, which were not conditioned for when calculating cell means. As was seen with the gender and racial earnings gaps, the mean labor earnings using the Cell Means Public Use series for those with less than a high-school degree, a high-school degree, and greater than a high-school degree very closely match the labor earnings observed using the Internal data. Thus, it does not seem that the 
benefits of using cell means are confined to questions relating to the conditioning criteria of race, gender, and employment status.

Once again, after 1995 when cell means were first provided by the Census Bureau the Unadjusted Public Use series successfully captures trends in education level earnings ratios found in the Internal data. However, the Unadjusted Public Use series is less accurate for calculating prior earnings gaps and contains a large artificial increase in the earnings of individuals with education beyond high school in 1995, reflecting the change in how the Census Bureau reported the labor earnings of individuals with topcoded income.

While the No Cell Mean Public Use and Consistent Topcode Public Use series avoid this large artificial increase in the education earnings gap in 1995, they also understate the mean earnings of workers with all three levels of education when compared to both our Cell Mean Public Use series and the Internal data between individuals with a high-school degree and those with some higher education in each year since 1975. And, the degree to which labor earnings are understated increases with education levels since individuals with greater than a high school degree are more likely to have higher labor earnings and thus are more likely to have income suppressed by topcoding. As a result, the returns to receiving higher education that can be found using the Consistent Topcode Public Use or No Cell Public Use series are smaller than would be found using data with more complete information about the upper tail of the income distribution.

\section{Comparison of Trends in Mean labor earnings by Gender, Race, and Education Level}

In addition to exploring the impact of topcoding on levels of the female-male, blackwhite, and education earnings gaps, we also examined how topcoding impacts the time-trends for these earnings gaps. Unfortunately, because of the trend break in 1975 in the Cell Mean Public 
Use and Internal series, we cannot observe trends across the entire 32 year sample. Instead, we look at the trends from 1975-1992 and 1993-2006 separately.

When looking at the trends we exclude the Unadjusted Public Use series since before 1995 it is identical to the No Cell Mean Public Use series and after 1995 it is nearly identical to our Cell Means Public Use series. Because the Unadjusted Public Use series is a combination of these two series, it cannot provide additional information about trends in the earnings gaps, and has a clear artificial jump in 1995 that makes it inferior to either of its component series individually. Therefore, we do not include this series in our analysis of trends in earnings ratios.

Figure 1 shows the trend in the female-male earnings ratio from 1975 through 1992 using each of the other four topcoding series: No Cell Mean Public Use, Consistent Topcode Public Use, Cell Mean Public Use, and Internal. In order to focus on the trends in the earnings ratios and not the levels, the earnings ratio in 1975 is normalized to 1 . The gender earnings gap trends during this period are similar across all four series —-women’s relative earnings improved dramatically. However, the No Cell Mean Public Use series slightly overstates this gain over the period.

The trend in the gender earnings gap from 1993-2006 can be seen in Figure 2 with 1993 normalized to 1 . As was the case prior to 1992, the Cell Mean Public Use and the Internal series have very similar trends. The Consistent Topcode Public Use series and the No Cell Mean Public Use series, however, have somewhat different trends. For example, the relative mean earnings of women is 0.711 that of men in 1993 using the Consistent Topcode Public Use series but is 0.663 in the Cell Mean Public Use series. By 2006 these values are 0.760, a rise of 6.93 percent in the No Cell Mean Public Use series, and 0.717, a rise of 8.15 percent in the Cell Mean Public Use series. 
While the trends seem to differ across the series, the direction and magnitudes of the difference between the trends varies greatly based on the years chosen. This is evident from Figure 2, where the No Cell Mean Public Use series is below the Internal series from 1995-1998 and from 2002-2004, indicating that the No Cell Mean Public Use series is understating the gains of women since 1993. In 1999-2000, the Internal series is lower, indicating that the No Cell Mean Public Use series is overstating the gains of women since 1995. Thus, unlike the levels of the earnings gap where the No Cell Mean and the Consistent Topcode Public Use series consistently overstated the relative earnings of women, this is not always the case for their trends.

A similar analysis can be seen for the trend in the black-white earnings ratio in Figures 3 and 4. As was the case for the female-male earnings ratio, the trend in the black-white earnings ratio using the Cell Mean Public Use series closely matches those in the Internal series. The No Cell Mean Public Use and Consistent Topcode Public Use series, however, less accurately captures trends in the Internal data - especially in the years since 1989. While the trends differ based on the topcoding series used, there do not appear to be any clear patterns where one series consistently finds that black workers are improving at a substantially faster or slower pace than is seen in the other series. Instead, depending on the year chosen the No Cell Mean Series and Consistent Topcode Series sometimes understate and sometimes overstate the relative decline in relative earnings of black workers since 1993.

Comparing the earnings ratio between individuals with post-secondary education and individuals with just a high school degree, in most years prior to 1992 (Figure 5) a similar pattern emerges to that seen for the female-male and black-white earnings ratios. The trend when using the Cell Mean Public Use series closely matches the Internal series. The No Cell Mean Public 
Use series and Consistent Topcode Public Use series are less accurate in capturing trends in the Internal data.

After 1992, the trend in the earnings gap between those with post-secondary education and those with only a high-school degree (Figure 6) shows a different pattern to those seen before or in the female-male or black-white earnings gap values in both time periods. In this period, the Cell Mean Public Use series consistently overstates the earnings gains compared to the earnings gains in the internal data. Thus, none of the three series using publicly available data closely match the trend found using the internal data. Upon closer inspection, however, this lack of accuracy using the Cell Means Public Use series after 1992 comes mainly from the choice of initial reference years. If 1994 rather than 1993 was the base year, the Cell Mean Public Use trend values would much more closely approximate the Internal series trend values. The reason is that the difference (0.026) between the Internal and the Cell Mean Public Use series values is greatest over the entire 32 year period in 1993. Thus, it is not that the Cell Mean Public Use series is unable to capture the trends in all years since 1993 in the Internal series, but rather that it does its poorest job of doing so when 1993 is the anchor year.

\section{Conclusion}

Even though topcoding is a well documented problem in the public use March CPS, until now the only available recourse to correct for time inconsistencies resulting from topcoding has been to place further restrictions on the data, either by using consistent topcoding or discarding the cell mean information provided by the Census Bureau after 1995. As a result, calculations have tended to understate true mean earnings in the United States. When comparing incomes across two groups within the population that are topcoded at different rates, all previously 
available topcode correction schemes will therefore lead to a misstatement of the earnings gap between the groups.

We were able to partially lift these topcoding constraints by obtaining access to the internal March CPS data files. While this internal data is also topcoded, the topcodes are substantially higher and more stable over time than those in the public use March CPS data. As a result, we were able to evaluate the impact of topcoding not by reducing the amount of data examined, but by expanding available data above the public topcode limits. We do so by extending the cell mean series provided by the Census Bureau to allow researchers using the public use March CPS data to estimate the incomes of individuals above the topcode threshold. Using this cell mean series with the public use March CPS data, we are able to closely match the results found using internal March CPS values from 1975-2004. Although the cell mean series best approximates the earnings levels in the internal March CPS for groups based on the conditioning criteria used when calculating cell means, earnings levels in the internal data for groups formed on other criteria such as education level can also be well approximated using the cell means series. Since our extended cell mean series is now available to the general public, researchers interested in exploring not just the trends in earnings gaps and ratios, but also more detailed questions about the underlying causes of these pay differences can use this extended cell mean series to answer these questions with precision similar to those obtained with access to the internal March CPS files.

Using the Cell Mean Public Use series to evaluate the levels of the female-male, blackwhite, and education earnings gaps, we found that the earnings gaps are substantially larger than those observed using the No Cell Mean Public Use series. In 2006, when using public use data without cell means, the mean earnings of women who work full-time, full-year made 74.9 
percent of that made by men, compared with just 71.7 percent of men's earnings once accounting for topcoding through the use of cell means. Similarly, in 2006 blacks mean earnings were just 71.2 percent of the mean earnings for whites when controlling for topcoding using cell means, compared with $73.4 \%$ without the use of cell means. And the mean earnings of individuals with some post-secondary education were 69 percent more than the mean earnings of individuals with just a high-school degree when cell means are used to control for topcoding, compared with 59 percent higher mean earnings when cell means are not used.

In addition to greatly differing levels for the earnings gaps, the trends in earnings gaps are also sensitive to the choice of topcode controls. We find that ignoring cell means and the earnings of individuals above the topcode thresholds will lead to an inaccurate perception of the trends in the female-male, black-white, and education earnings ratios. However, unlike what was seen for the levels of the earnings gap, the direction of this error in trends is not consistent across the years and is sensitive to the precise years chosen when calculating the trends. As a result, using public use data without cell means will overstate the relative increase in earnings of women, blacks, and the less-educated in some years, but will understate the relative increase in their earnings in other years. 


\section{ENDNOTES}

${ }^{1}$ Each year the U.S. Census Bureau releases its yearly average income and poverty rates from the March CPS using these data (U.S. Census Bureau, 2007). As we will discuss in some detail below these official values are based on the internal March CPS data that is not available, except under certain conditions, to researchers outside of the U.S. Census Bureau.

${ }^{2}$ For a discussion of how topcoding impacts comparisons of income between males with and without work limitations, see Burkhauser and Larrimore (2008)

${ }^{3}$ In order to reduce the impact of labor supply decisions on our analysis of labor earnings, we follow the convention used by the U.S. Census Bureau in their annual analysis of earnings income and restrict our sample to individuals over the age of 15 who work full time (35+ hours per week) and full year (50+ weeks) for the income year (U.S. Census Bureau 2007). We also restrict our sample to individuals who are not in the military and do not reside in group quarters. Additionally, to report income consistently over time, all income has been adjusted to 2006 dollars using the CPI-U-RS reported by the Bureau of Labor Statistics.

${ }^{4}$ A common refinement on the No Cell Mean approach is to assign topcoded individuals income that is a fixed multiple of the topcode level—e.g. 1.3 to 1.5. (See: Blau and Kahn 2000). While this comes closer to capturing levels of earnings gaps, the trends are nearly identical to those seen in the No Cell Mean series and does not account for changes in the distribution of incomes above the topcode thresholds over time. For the sake of brevity we do not include the set of results using this method, but they are available from the authors upon request.

${ }^{5}$ In 2006 the Census Bureau granted us permission to use the internal March CPS to test the sensitivity of measured income inequality to alternative methods of providing additional information on topcoded persons in the public use March CPS. In addition, we were allowed to provide researchers without access to the internal March CPS data with this information, as long as in doing so, we do not unduly risk the confidentially of CPS respondents. In creating our extended cell mean series for each source of labor earnings, we divide the population by gender, race, and employment status, the same categories the Census Bureau uses to produce their cell means. We then replace the topcoded income value with the weighted mean-income of all individuals with the same set of demographic characteristics who are topcoded from that source of income in the public use March CPS. Like the Census Bureau, to protect the confidentiality of respondents, when less than five individuals are topcoded from an income source; 
we combine those individuals with individuals from a similar source to obtain a cell-size of five or more to generate a cell mean. See Larrimore, Burkhauser, Feng, and Zayatz (2008) for a more detailed discussion of our extended cell mean series and the procedures we followed to protect the confidentiality of respondents. 


\section{REFERENCES}

Blau, Francine D. and Lawrence M. Kahn. 2000. "Gender Differences in Pay.” Journal of Economic Perspectives 14(4): 75-99

Blau, Francine D. and Lawrence M. Kahn. 1997. "Swimming Upstream: Trends in the Gender Wage Differential in the 1980s.” Journal of Labor Economics 15(1): 1-42

Bound, John and Richard B. Freeman. 1992. "What Went Wrong? The Erosion of Relative Earnings and Employment Among Young Black Men in the 1980s." Quarterly Journal of Economics 107(1): 201-232

Burkhauser, Richard V., J.S. Butler, Shuaizhang Feng, and Andrew J. Houtenville. 2004. "Long Term Trends in Earnings Inequality: What the CPS Can Tell Us.” Economic Letters 82 (2): 295-299.

Burkhauser, Richard V., Kenneth A. Couch, Andrew J. Houtenville, and Ludmila Rovba. 2004. "Income Inequality in the 1990s: Re-Forging a Lost Relationship?" Journal of Income Distribution 12 (3-4): 8-35.

Burkhauser, Richard V., Shuaizhang Feng, and Stephen Jenkins. 2007. "Using a P90/P10 Ratio to Measure Inequality Trends with the Public Use Current Population Survey: A View from Inside the Census Bureau Vaults.” ISER WP 2007-14, June, 2007.

Burkhauser, Richard V and Jeff Larrimore. 2008. "Trends in the Relative Household Income of Working-Age Men with Work Limitations: Correcting the Record using Internal Current Population Survey Data." Center for Economic Studies Working Paper Series CES-WP08-05, <http://www.ces.census.gov/index.php/ces/cespapers>.

Card, David and John E. DiNardo. 2002. "Skill-Biased Technological Change and Rising Wage Inequality: Some Problems and Puzzles.” Journal of Labor Economics 20(4).

Couch, Kenneth and Mary C. Daly. 2002. "Black-white wage inequality in the 1990s: A decade of progress.” Economic Inquiry 40(1): 31-42.

DeNavas-Walt, Carmen, Bernadette D. Proctor, and Jessica Smith, 2007. U.S. Census Bureau, Current Population Reports P60-233, Income, Poverty, and Health Insurance Coverage in the United States: 2006. U.S. Government Printing Office, Washington DC,

Devine, Theresa J. 1994. "Characteristics of Self-Employed Women in the United States." Monthly Labor Review 117(3): 20-34.

Feng, Shuaizhang, Richard V. Burkhauser, and J.S. Butler. 2006. "Levels and Long-Term Trends in Earnings Inequality: Overcoming Current Population Survey Censoring Problems Using the GB2 Distribution.” Journal of Business and Economic Statistics 24 (1): 57-62. 
Institute for Womens Policy Research. 2008. “The Gender Wage Ratio: Women’s and Men’s

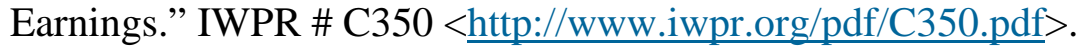

Juhn, Chinhui, Kevin M. Murphy, and Brooks Pierce. 1991. “Accounting for the Slowdiwn in Black-White Wage Convergence.” in Marvin Kosters (Ed), Workers and their Wages, AEI Press, Washington DC.

Juhn, Chinhui. 2003. "Labor Market Dropouts and Trends in the Wages of Black and White Men.” Industrial and Labor Relations Review 56(4): 643-662.

Larrimore, Jeff, Richard V. Burkhauser, Shuaizhang Feng and Laura Zayatz, 2008. "Consistent Cell Means for Topcoded Incomes in the Public Use March CPS (1975-2007).” NBER Working Paper 13941.

Levy, Frank and Richard J. Murnane. 1992. "U.S. Earnings Levels and Earnings Inequality: A Review of Recent Trends and Proposed Explanations.” Journal of Economic Literature 30 (3): 1333-1381.

National Women’s Law Center. 2006. “The Paycheck Fairness Act: Helping to Close the Gap for Women.” < http://www.pay-equity.org/PDFs/PaycheckFairnessActApr06.pdf>.

O’Neill, June. 2003. “The Gender Wage Gap, circa 2000.” American Economic Review: AEA Papers and Proceedings 93(2): 309-314.

U.S. Census Bureau. 2007. “Current Population Survey Annual Social and Economic Supplement Technical Documentation.” Washington DC: GPO.

Welniak, Edward J. 2003. “Measuring Household Income Inequality Using the CPS.” in James Dalton and Beth Kilss (Eds.), Special Studies in Federal Tax Statistics 2003, Statistics of Income Directorate, Inland Revenue Service, Washington DC. 
Table 1. Percentage of Full-Time and Full-Year Workers who are Topcoded on their Labor Earnings by Gender, Race, and Education Level (1987-2006).

\begin{tabular}{|c|c|c|c|c|c|c|c|c|c|c|c|}
\hline $\begin{array}{c}\text { Income } \\
\text { Year }\end{array}$ & $\begin{array}{c}\text { Female } \\
\text { (1) }\end{array}$ & $\begin{array}{l}\text { Male } \\
(2)\end{array}$ & $\begin{array}{l}\text { Ratio } \\
(1) /(2)\end{array}$ & $\begin{array}{c}\text { Black } \\
\text { (3) }\end{array}$ & $\begin{array}{l}\text { White } \\
\text { (4) }\end{array}$ & $\begin{array}{l}\text { Ratio } \\
(3) /(4)\end{array}$ & $\begin{array}{l}\text { Less than a } \\
\text { High School } \\
\text { Degree } \\
\text { (7) }\end{array}$ & $\begin{array}{c}\text { High } \\
\text { School } \\
\text { Graduate } \\
\text { (8) }\end{array}$ & $\begin{array}{c}\text { Education } \\
\text { Beyond } \\
\text { High School } \\
\text { (9) }\end{array}$ & $\begin{array}{l}\text { Ratio } \\
(8) /(7)\end{array}$ & $\begin{array}{l}\text { Ratio } \\
(9) /(8)\end{array}$ \\
\hline 1975 & $0.02 \%$ & $1.18 \%$ & 0.02 & $0.00 \%$ & $0.91 \%$ & 0.00 & $0.09 \%$ & $0.28 \%$ & $1.73 \%$ & 3.14 & 6.24 \\
\hline 1976 & $0.11 \%$ & $1.41 \%$ & 0.08 & $0.06 \%$ & $1.13 \%$ & 0.06 & $0.16 \%$ & $0.24 \%$ & $2.16 \%$ & 1.50 & 8.84 \\
\hline 1977 & $0.06 \%$ & $1.63 \%$ & 0.04 & $0.09 \%$ & $1.30 \%$ & 0.07 & $0.11 \%$ & $0.27 \%$ & $2.42 \%$ & 2.38 & 8.99 \\
\hline 1978 & $0.11 \%$ & $2.20 \%$ & 0.05 & $0.18 \%$ & $1.74 \%$ & 0.10 & $0.36 \%$ & $0.41 \%$ & $3.03 \%$ & 1.13 & 7.44 \\
\hline 1979 & $0.19 \%$ & $2.75 \%$ & 0.07 & $0.29 \%$ & $2.12 \%$ & 0.14 & $0.35 \%$ & $0.59 \%$ & $3.68 \%$ & 1.67 & 6.26 \\
\hline 1980 & $0.24 \%$ & $3.37 \%$ & 0.07 & $0.45 \%$ & $2.54 \%$ & 0.18 & $0.29 \%$ & $0.79 \%$ & $4.36 \%$ & 2.74 & 5.55 \\
\hline 1981 & $0.08 \%$ & $1.27 \%$ & 0.06 & $0.00 \%$ & $0.98 \%$ & 0.00 & $0.15 \%$ & $0.22 \%$ & $1.64 \%$ & 1.45 & 7.33 \\
\hline 1982 & $0.16 \%$ & $1.76 \%$ & 0.09 & $0.33 \%$ & $1.30 \%$ & 0.26 & $0.07 \%$ & $0.34 \%$ & $2.18 \%$ & 4.70 & 6.44 \\
\hline 1983 & $0.13 \%$ & $1.90 \%$ & 0.07 & $0.03 \%$ & $1.45 \%$ & 0.02 & $0.25 \%$ & $0.34 \%$ & $2.26 \%$ & 1.35 & 6.64 \\
\hline 1984 & $0.08 \%$ & $1.05 \%$ & 0.08 & $0.03 \%$ & $0.80 \%$ & 0.03 & $0.15 \%$ & $0.19 \%$ & $1.24 \%$ & 1.31 & 6.47 \\
\hline 1985 & $0.08 \%$ & $1.18 \%$ & 0.07 & $0.18 \%$ & $0.89 \%$ & 0.20 & $0.16 \%$ & $0.10 \%$ & $1.44 \%$ & 0.65 & 14.09 \\
\hline 1986 & $0.11 \%$ & $1.59 \%$ & 0.07 & $0.25 \%$ & $1.21 \%$ & 0.21 & $0.17 \%$ & $0.16 \%$ & $1.89 \%$ & 0.95 & 11.50 \\
\hline 1987 & $0.20 \%$ & $1.49 \%$ & 0.13 & $0.36 \%$ & $1.12 \%$ & 0.32 & $0.22 \%$ & $0.27 \%$ & $1.74 \%$ & 1.23 & 6.54 \\
\hline 1988 & $0.25 \%$ & $1.83 \%$ & 0.14 & $0.55 \%$ & $1.34 \%$ & 0.41 & $0.31 \%$ & $0.32 \%$ & $2.10 \%$ & 1.05 & 6.47 \\
\hline 1989 & $0.33 \%$ & $2.53 \%$ & 0.13 & $0.20 \%$ & $1.94 \%$ & 0.10 & $0.19 \%$ & $0.44 \%$ & $2.92 \%$ & 2.30 & 6.67 \\
\hline 1990 & $0.28 \%$ & $2.49 \%$ & 0.11 & $0.28 \%$ & $1.87 \%$ & 0.15 & $0.26 \%$ & $0.36 \%$ & $2.85 \%$ & 1.35 & 7.99 \\
\hline 1991 & $0.43 \%$ & $2.53 \%$ & 0.17 & $0.31 \%$ & $1.95 \%$ & 0.16 & $0.28 \%$ & $0.41 \%$ & $2.84 \%$ & 1.48 & 6.96 \\
\hline 1992 & $0.39 \%$ & $2.98 \%$ & 0.13 & $0.37 \%$ & $2.22 \%$ & 0.17 & $0.22 \%$ & $0.35 \%$ & $3.24 \%$ & 1.59 & 9.39 \\
\hline 1993 & $0.66 \%$ & $3.51 \%$ & 0.19 & $0.80 \%$ & $2.68 \%$ & 0.30 & $0.30 \%$ & $0.56 \%$ & $3.78 \%$ & 1.91 & 6.70 \\
\hline 1994 & 0.83\% & $3.98 \%$ & 0.21 & $0.94 \%$ & $3.13 \%$ & 0.30 & $0.37 \%$ & $0.65 \%$ & $4.34 \%$ & 1.75 & 6.67 \\
\hline 1995 & $0.58 \%$ & $2.21 \%$ & 0.26 & $0.48 \%$ & $1.80 \%$ & 0.27 & $0.26 \%$ & $0.59 \%$ & $2.35 \%$ & 2.25 & 3.97 \\
\hline 1996 & $0.59 \%$ & $2.27 \%$ & 0.26 & $0.69 \%$ & $1.88 \%$ & 0.37 & $0.24 \%$ & $0.63 \%$ & $2.40 \%$ & 2.69 & 3.78 \\
\hline 1997 & $0.88 \%$ & $2.74 \%$ & 0.32 & $0.52 \%$ & $2.31 \%$ & 0.22 & $0.78 \%$ & $0.66 \%$ & $2.96 \%$ & 0.85 & 4.47 \\
\hline 1998 & $0.76 \%$ & $2.83 \%$ & 0.27 & $0.79 \%$ & $2.32 \%$ & 0.34 & $0.39 \%$ & $0.64 \%$ & $3.05 \%$ & 1.62 & 4.80 \\
\hline 1999 & $0.86 \%$ & $3.38 \%$ & 0.25 & $1.06 \%$ & $2.83 \%$ & 0.37 & $0.43 \%$ & $0.78 \%$ & $3.59 \%$ & 1.80 & 4.62 \\
\hline 2000 & $1.07 \%$ & $3.58 \%$ & 0.30 & $1.03 \%$ & $3.01 \%$ & 0.34 & $0.99 \%$ & $0.74 \%$ & $3.83 \%$ & 0.75 & 5.17 \\
\hline 2001 & $1.10 \%$ & $3.94 \%$ & 0.28 & $0.93 \%$ & $3.30 \%$ & 0.28 & $0.85 \%$ & $1.02 \%$ & $4.01 \%$ & 1.20 & 3.92 \\
\hline 2002 & $0.55 \%$ & $2.30 \%$ & 0.24 & $0.78 \%$ & $1.85 \%$ & 0.42 & $0.27 \%$ & $0.64 \%$ & $2.27 \%$ & 2.36 & 3.57 \\
\hline 2003 & $0.73 \%$ & $2.29 \%$ & 0.32 & $0.71 \%$ & $1.96 \%$ & 0.36 & $0.42 \%$ & $0.68 \%$ & $2.33 \%$ & 1.63 & 3.42 \\
\hline 2004 & $0.57 \%$ & $2.23 \%$ & 0.26 & $0.61 \%$ & $1.84 \%$ & 0.33 & $0.31 \%$ & $0.59 \%$ & $2.23 \%$ & 1.88 & 3.80 \\
\hline 2005 & $0.85 \%$ & $2.48 \%$ & 0.34 & $0.85 \%$ & $2.21 \%$ & 0.38 & $0.32 \%$ & $0.55 \%$ & $2.67 \%$ & 1.72 & 4.85 \\
\hline 2006 & $0.93 \%$ & $2.62 \%$ & 0.35 & $0.91 \%$ & $2.34 \%$ & 0.39 & $0.45 \%$ & $0.57 \%$ & $2.81 \%$ & 1.27 & 4.93 \\
\hline
\end{tabular}

Source: Author’s calculations using public use March CPS data. 
Table 2. Mean Labor Earnings and Earnings Gap among Full-Time, Full-Year workers by gender (1975-2006).

\begin{tabular}{|c|c|c|c|c|c|c|c|c|c|c|c|c|c|c|c|}
\hline \multirow[b]{3}{*}{$\begin{array}{c}\text { Income } \\
\text { year }\end{array}$} & \multicolumn{12}{|c|}{ Public Use } & \multirow{2}{*}{\multicolumn{3}{|c|}{ Internal }} \\
\hline & \multicolumn{3}{|c|}{ No Cell Mean } & \multicolumn{3}{|c|}{ Unadjusted } & \multicolumn{3}{|c|}{ Consistent Topcode } & \multicolumn{3}{|c|}{ Cell Mean } & & & \\
\hline & $\begin{array}{c}\text { Female } \\
\text { (1) }\end{array}$ & $\begin{array}{c}\text { Male } \\
(2)\end{array}$ & $\begin{array}{c}\text { Ratio } \\
(1) /(2)\end{array}$ & $\begin{array}{c}\text { Female } \\
\text { (4) }\end{array}$ & $\begin{array}{l}\text { Male } \\
\text { (5) }\end{array}$ & $\begin{array}{c}\text { Ratio } \\
(4) /(5)\end{array}$ & $\begin{array}{c}\text { Female } \\
\text { (7) }\end{array}$ & $\begin{array}{c}\text { Male } \\
\text { (8) }\end{array}$ & $\begin{array}{c}\text { Ratio } \\
(7) /(8)\end{array}$ & $\begin{array}{c}\text { Female } \\
\text { (10) }\end{array}$ & $\begin{array}{c}\text { Male } \\
(11)\end{array}$ & $\begin{array}{c}\text { Ratio } \\
(10) /(11)\end{array}$ & $\begin{array}{c}\text { Female } \\
\text { (13) }\end{array}$ & $\begin{array}{l}\text { Male } \\
(14)\end{array}$ & $\begin{array}{c}\text { Ratio } \\
(13) /(14)\end{array}$ \\
\hline 1975 & 26831 & 47512 & 0.565 & 26831 & 47512 & 0.565 & 26782 & 45797 & 0.585 & 26836 & 48177 & 0.557 & 26914 & 48233 & 0.558 \\
\hline 1976 & 27487 & 48026 & 0.572 & 27487 & 48026 & 0.572 & 27390 & 46541 & 0.589 & 27547 & 48749 & 0.565 & 27540 & 48753 & 0.565 \\
\hline 1977 & 27432 & 48409 & 0.567 & 27432 & 48409 & 0.567 & 27378 & 46965 & 0.583 & 27450 & 49449 & 0.555 & 27459 & 49278 & 0.557 \\
\hline 1978 & 27861 & 48613 & 0.573 & 27861 & 48613 & 0.573 & 27803 & 47453 & 0.586 & 27891 & 49642 & 0.562 & 27889 & 49719 & 0.561 \\
\hline 1979 & 27887 & 48105 & 0.580 & 27887 & 48105 & 0.580 & 27822 & 47292 & 0.588 & 27960 & 49655 & 0.563 & 27953 & 49480 & 0.565 \\
\hline 1980 & 27799 & 46391 & 0.599 & 27799 & 46391 & 0.599 & 27759 & 45751 & 0.607 & 27871 & 47111 & 0.592 & 27869 & 47790 & 0.583 \\
\hline 1981 & 27710 & 46702 & 0.593 & 27710 & 46702 & 0.593 & 27636 & 45222 & 0.611 & 27733 & 47205 & 0.588 & 27736 & 47203 & 0.588 \\
\hline 1982 & 28571 & 46869 & 0.610 & 28571 & 46869 & 0.610 & 28428 & 45299 & 0.628 & 28627 & 47379 & 0.604 & 28627 & 47436 & 0.603 \\
\hline 1983 & 28999 & 46681 & 0.621 & 28999 & 46681 & 0.621 & 28893 & 45233 & 0.639 & 29036 & 47316 & 0.614 & 29036 & 47317 & 0.614 \\
\hline 1984 & 29519 & 47812 & 0.617 & 29519 & 47812 & 0.617 & 29362 & 45910 & 0.640 & 29519 & 47812 & 0.617 & 29519 & 47812 & 0.617 \\
\hline 1985 & 30305 & 48177 & 0.629 & 30305 & 48177 & 0.629 & 30171 & 46426 & 0.650 & 30348 & 48543 & 0.625 & 30341 & 48997 & 0.619 \\
\hline 1986 & 31292 & 49396 & 0.633 & 31292 & 49396 & 0.633 & 31131 & 47674 & 0.653 & 31376 & 50515 & 0.621 & 31380 & 50514 & 0.621 \\
\hline 1987 & 31777 & 49457 & 0.643 & 31777 & 49457 & 0.643 & 31579 & 47799 & 0.661 & 31961 & 50768 & 0.630 & 31963 & 50800 & 0.629 \\
\hline 1988 & 32236 & 49519 & 0.651 & 32236 & 49519 & 0.651 & 32053 & 48135 & 0.666 & 32441 & 50909 & 0.637 & 32458 & 50933 & 0.637 \\
\hline 1989 & 32769 & 49900 & 0.657 & 32769 & 49900 & 0.657 & 32589 & 48504 & 0.672 & 32974 & 52033 & 0.634 & 32982 & 52086 & 0.633 \\
\hline 1990 & 32567 & 48136 & 0.677 & 32567 & 48136 & 0.677 & 32411 & 46857 & 0.692 & 32807 & 50078 & 0.655 & 32795 & 50122 & 0.654 \\
\hline 1991 & 32909 & 48183 & 0.683 & 32909 & 48183 & 0.683 & 32718 & 47142 & 0.694 & 33117 & 49793 & 0.665 & 33104 & 49835 & 0.664 \\
\hline 1992 & 33514 & 48351 & 0.693 & 33514 & 48351 & 0.693 & 33395 & 47404 & 0.704 & 33791 & 50459 & 0.670 & 33791 & 50482 & 0.669 \\
\hline 1993 & 33701 & 47889 & 0.704 & 33701 & 47889 & 0.704 & 33572 & 47211 & 0.711 & 34742 & 52387 & 0.663 & 34774 & 52402 & 0.664 \\
\hline 1994 & 34240 & 48326 & 0.709 & 34240 & 48326 & 0.709 & 34174 & 47914 & 0.713 & 35297 & 53029 & 0.666 & 35340 & 53040 & 0.666 \\
\hline 1995 & 34295 & 49550 & 0.692 & 34843 & 53217 & 0.655 & 33997 & 47684 & 0.713 & 34911 & 53182 & 0.656 & 34859 & 53221 & 0.655 \\
\hline 1996 & 35187 & 49858 & 0.706 & 36333 & 53927 & 0.674 & 34797 & 48046 & 0.724 & 36326 & 53937 & 0.673 & 36323 & 53963 & 0.673 \\
\hline 1997 & 35734 & 50525 & 0.707 & 36667 & 54840 & 0.669 & 35312 & 48745 & 0.724 & 36690 & 54828 & 0.669 & 36638 & 54857 & 0.668 \\
\hline 1998 & 36713 & 51373 & 0.715 & 37886 & 55564 & 0.682 & 36386 & 49895 & 0.729 & 37914 & 55545 & 0.683 & 37887 & 55578 & 0.682 \\
\hline 1999 & 36941 & 52918 & 0.698 & 37412 & 55767 & 0.671 & 36685 & 51553 & 0.712 & 37707 & 57637 & 0.654 & 37662 & 57693 & 0.653 \\
\hline 2000 & 37321 & 53093 & 0.703 & 38250 & 59158 & 0.647 & 37090 & 51957 & 0.714 & 38248 & 59141 & 0.647 & 38203 & 59300 & 0.644 \\
\hline 2001 & 38362 & 52825 & 0.726 & 40269 & 58863 & 0.684 & 38203 & 52096 & 0.733 & 40118 & 58952 & 0.681 & 40308 & 58858 & 0.685 \\
\hline 2002 & 39097 & 54718 & 0.715 & 40118 & 58893 & 0.681 & 38690 & 52718 & 0.734 & 40118 & 58893 & 0.681 & 40152 & 58887 & 0.682 \\
\hline 2003 & 39635 & 54502 & 0.727 & 40759 & 58251 & 0.700 & 39172 & 52827 & 0.742 & 40759 & 58251 & 0.700 & 40780 & 58266 & 0.700 \\
\hline 2004 & 39293 & 53575 & 0.733 & 40416 & 57685 & 0.701 & 38959 & 52016 & 0.749 & 40416 & 57685 & 0.701 & 40373 & 57686 & 0.700 \\
\hline 2005 & 39460 & 53438 & 0.738 & 40344 & 58088 & 0.695 & 39070 & 51742 & 0.755 & 40344 & 58088 & 0.695 & & & \\
\hline 2006 & 39811 & 53180 & 0.749 & 41457 & 57800 & 0.717 & 39299 & 51684 & 0.760 & 41457 & 57800 & 0.717 & & & \\
\hline
\end{tabular}

Source: Author's calculations using public and internal March CPS data. 
Table 3. Mean Labor Earnings and Earnings Gap among Full-Time, Full-Year workers by race (1975-2006).

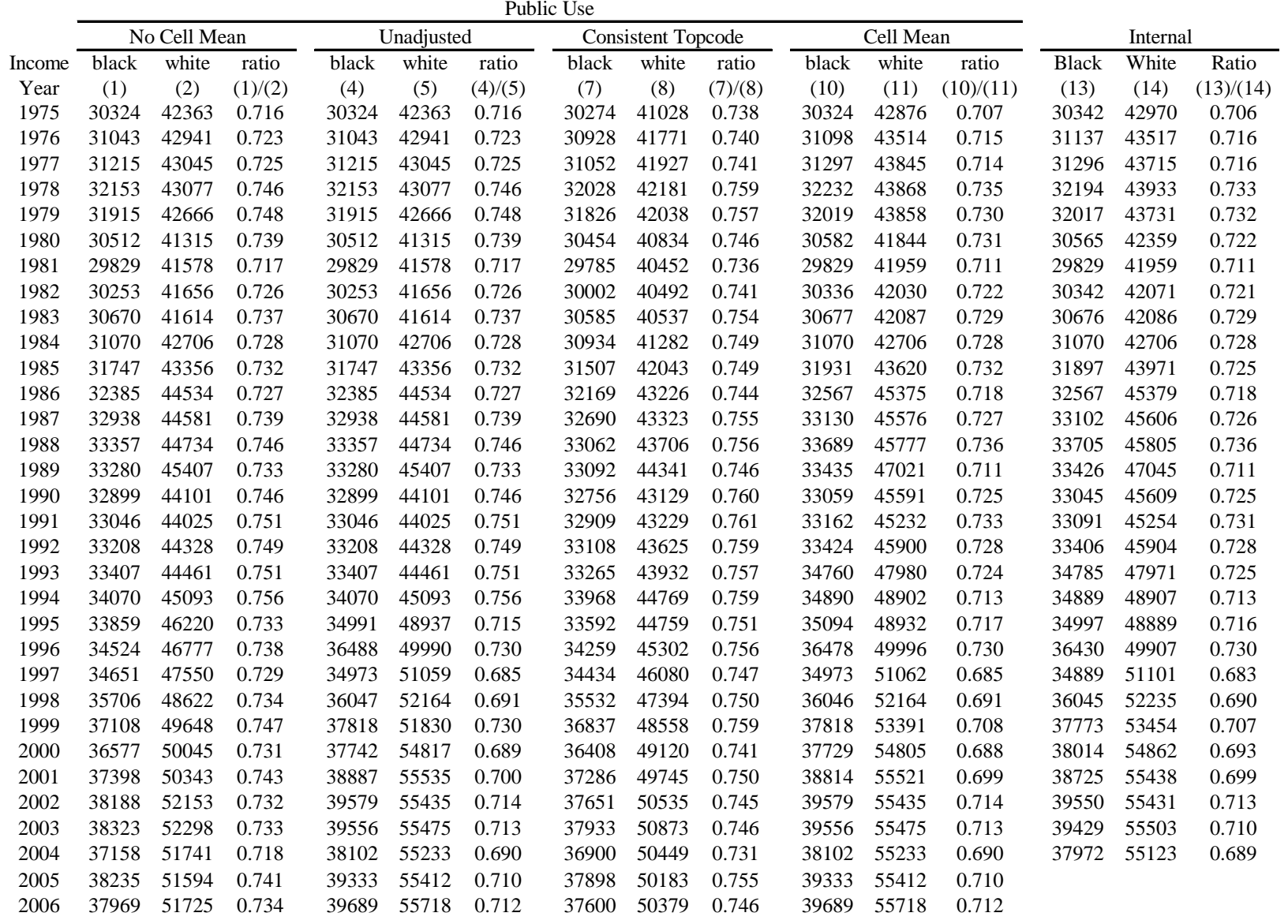

Source: Author's calculations using public and internal March CPS data. 
Table 4. Mean Labor Earnings and Earnings Gap among Full-Time, Full-Year workers by educational attainment (1975-2006).

\begin{tabular}{|c|c|c|c|c|c|c|c|c|c|c|c|c|c|c|c|}
\hline & \multicolumn{5}{|c|}{ No Cell Mean Public Use } & \multicolumn{5}{|c|}{ Unadjusted Public Use } & \multicolumn{5}{|c|}{ Consistent Topcode Public Use } \\
\hline & Less than & & Education & & & Less than & & Education & & & Less than & & Education & & \\
\hline & a High & High & Beyond & & & a High & High & Beyond & & & a High & High & Beyond & & \\
\hline & School & School & High & & & School & School & High & & & School & School & High & & \\
\hline $\begin{array}{c}\text { Income } \\
\text { year }\end{array}$ & $\begin{array}{l}\text { Degree } \\
\text { (1) }\end{array}$ & $\begin{array}{l}\text { Graduate } \\
\text { (2) }\end{array}$ & $\begin{array}{l}\text { School } \\
\text { (3) }\end{array}$ & $\begin{array}{l}\text { Ratio } \\
(2) /(1)\end{array}$ & $\begin{array}{l}\text { Ratio } \\
(3) /(2)\end{array}$ & $\begin{array}{l}\text { Degree } \\
\text { (6) }\end{array}$ & $\begin{array}{c}\text { Graduate } \\
\text { (7) }\end{array}$ & $\begin{array}{l}\text { School } \\
\text { (8) }\end{array}$ & $\begin{array}{l}\text { Ratio } \\
\text { (6)/(7) }\end{array}$ & $\begin{array}{c}\text { Ratio } \\
(7) /(8)\end{array}$ & $\begin{array}{l}\text { Degree } \\
(11)\end{array}$ & $\begin{array}{c}\text { Graduate } \\
\text { (12) }\end{array}$ & $\begin{array}{l}\text { School } \\
\text { (13) }\end{array}$ & $\begin{array}{c}\text { Ratio } \\
(12) /(11)\end{array}$ & $\begin{array}{c}\text { Ratio } \\
(13) /(12)\end{array}$ \\
\hline 1975 & 31108 & 36568 & 50423 & 1.18 & 1.38 & 31108 & 36568 & 50423 & 1.18 & 1.38 & 30870 & 36123 & 48017 & 1.17 & 1.33 \\
\hline 1976 & 31829 & 36743 & 51008 & 1.15 & 1.39 & 31829 & 36743 & 51008 & 1.15 & 1.39 & 31621 & 36429 & 48837 & 1.15 & 1.34 \\
\hline 1977 & 31382 & 37119 & 50613 & 1.18 & 1.36 & 31382 & 37119 & 50613 & 1.18 & 1.36 & 31261 & 36798 & 48579 & 1.18 & 1.32 \\
\hline 1978 & 32066 & 36940 & 50231 & 1.15 & 1.36 & 32066 & 36940 & 50231 & 1.15 & 1.36 & 31888 & 36693 & 48669 & 1.15 & 1.33 \\
\hline 1979 & 31800 & 36489 & 49408 & 1.15 & 1.35 & 31800 & 36489 & 49408 & 1.15 & 1.35 & 31692 & 36302 & 48329 & 1.15 & 1.33 \\
\hline 1980 & 30141 & 35295 & 47512 & 1.17 & 1.35 & 30141 & 35295 & 47512 & 1.17 & 1.35 & 30093 & 35160 & 46682 & 1.17 & 1.33 \\
\hline 1981 & 29379 & 34573 & 48208 & 1.18 & 1.39 & 29379 & 34573 & 48208 & 1.18 & 1.39 & 29250 & 34288 & 46338 & 1.17 & 1.35 \\
\hline 1982 & 28264 & 34323 & 48301 & 1.21 & 1.41 & 28264 & 34323 & 48301 & 1.21 & 1.41 & 28156 & 33993 & 46411 & 1.21 & 1.37 \\
\hline 1983 & 28892 & 33783 & 48228 & 1.17 & 1.43 & 28892 & 33783 & 48228 & 1.17 & 1.43 & 28703 & 33544 & 46508 & 1.17 & 1.39 \\
\hline 1984 & 28875 & 34731 & 49222 & 1.20 & 1.42 & 28875 & 34731 & 49222 & 1.20 & 1.42 & 28645 & 34342 & 47019 & 1.20 & 1.37 \\
\hline 1985 & 28657 & 34751 & 50023 & 1.21 & 1.44 & 28657 & 34751 & 50023 & 1.21 & 1.44 & 28460 & 34477 & 47962 & 1.21 & 1.39 \\
\hline 1986 & 28999 & 35432 & 51404 & 1.22 & 1.45 & 28999 & 35432 & 51404 & 1.22 & 1.45 & 28833 & 35196 & 49351 & 1.22 & 1.40 \\
\hline 1987 & 29838 & 35556 & 51371 & 1.19 & 1.44 & 29838 & 35556 & 51371 & 1.19 & 1.44 & 29607 & 35268 & 49437 & 1.19 & 1.40 \\
\hline 1988 & 28965 & 35570 & 51381 & 1.23 & 1.44 & 28965 & 35570 & 51381 & 1.23 & 1.44 & 28758 & 35299 & 49824 & 1.23 & 1.41 \\
\hline 1989 & 28311 & 35693 & 52139 & 1.26 & 1.46 & 28311 & 35693 & 52139 & 1.26 & 1.46 & 28207 & 35414 & 50562 & 1.26 & 1.43 \\
\hline 1990 & 27396 & 34363 & 50726 & 1.25 & 1.48 & 27396 & 34363 & 50726 & 1.25 & 1.48 & 27288 & 34155 & 49277 & 1.25 & 1.44 \\
\hline 1991 & 26801 & 33817 & 50502 & 1.26 & 1.49 & 26801 & 33817 & 50502 & 1.26 & 1.49 & 26674 & 33641 & 49342 & 1.26 & 1.47 \\
\hline 1992 & 26628 & 33907 & 50390 & 1.27 & 1.49 & 26628 & 33907 & 50390 & 1.27 & 1.49 & 26543 & 33792 & 49375 & 1.27 & 1.46 \\
\hline 1993 & 25813 & 33645 & 50024 & 1.30 & 1.49 & 25813 & 33645 & 50024 & 1.30 & 1.49 & 25763 & 33517 & 49303 & 1.30 & 1.47 \\
\hline 1994 & 26267 & 34184 & 50517 & 1.30 & 1.48 & 26267 & 34184 & 50517 & 1.30 & 1.48 & 26188 & 34084 & 50109 & 1.30 & 1.47 \\
\hline 1995 & 26475 & 34517 & 51559 & 1.30 & 1.49 & 26730 & 35392 & 55241 & 1.32 & 1.56 & 26383 & 34077 & 49662 & 1.29 & 1.46 \\
\hline 1996 & 26598 & 35021 & 52232 & 1.32 & 1.49 & 27120 & 36035 & 56638 & 1.33 & 1.57 & 26302 & 34651 & 50319 & 1.32 & 1.45 \\
\hline 1997 & 27616 & 34989 & 52927 & 1.27 & 1.51 & 29064 & 35712 & 57406 & 1.23 & 1.61 & 27187 & 34657 & 51043 & 1.27 & 1.47 \\
\hline 1998 & 26501 & 35332 & 54392 & 1.33 & 1.54 & 27209 & 35984 & 59060 & 1.32 & 1.64 & 26327 & 35139 & 52773 & 1.33 & 1.50 \\
\hline 1999 & 26592 & 35902 & 55339 & 1.35 & 1.54 & 26926 & 36457 & 58185 & 1.35 & 1.60 & 26421 & 35630 & 53959 & 1.35 & 1.51 \\
\hline 2000 & 26610 & 36290 & 55406 & 1.36 & 1.53 & 27751 & 37243 & 61417 & 1.34 & 1.65 & 26379 & 36092 & 54253 & 1.37 & 1.50 \\
\hline 2001 & 27031 & 35918 & 55939 & 1.33 & 1.56 & 28294 & 37302 & 62334 & 1.32 & 1.67 & 26892 & 35765 & 55206 & 1.33 & 1.54 \\
\hline 2002 & 27175 & 36370 & 57781 & 1.34 & 1.59 & 27864 & 37318 & 61984 & 1.34 & 1.66 & 26936 & 35976 & 55780 & 1.34 & 1.55 \\
\hline 2003 & 27246 & 36724 & 57576 & 1.35 & 1.57 & 27858 & 37481 & 61527 & 1.35 & 1.64 & 27062 & 36455 & 55787 & 1.35 & 1.53 \\
\hline 2004 & 26343 & 36164 & 57066 & 1.37 & 1.58 & 26757 & 37118 & 61331 & 1.39 & 1.65 & 26247 & 35858 & 55474 & 1.37 & 1.55 \\
\hline 2005 & 26560 & 35914 & 56903 & 1.35 & 1.58 & 26944 & 36731 & 61567 & 1.36 & 1.68 & 26378 & 35599 & 55170 & 1.35 & 1.55 \\
\hline 2006 & 26791 & 35753 & 56764 & 1.33 & 1.59 & 27493 & 36589 & 61830 & 1.33 & 1.69 & 26607 & 35515 & 55115 & 1.33 & 1.55 \\
\hline
\end{tabular}

Source: Author’s calculations using public and internal March CPS data. 
Table 4 (continued):

\begin{tabular}{|c|c|c|c|c|c|c|c|c|c|c|}
\hline & \multicolumn{5}{|c|}{ Cell Mean Public Use } & \multicolumn{5}{|c|}{ Internal } \\
\hline & Less than & & Education & & & Less than & & & & \\
\hline & a High & & Beyond & & & a High & High & Education & & \\
\hline & School & High School & High & & & School & School & Beyond & & \\
\hline $\begin{array}{l}\text { Income } \\
\text { year }\end{array}$ & $\begin{array}{l}\text { Degree } \\
(16)\end{array}$ & $\begin{array}{c}\text { Graduate } \\
\text { (17) }\end{array}$ & $\begin{array}{c}\text { School } \\
(18)\end{array}$ & $\begin{array}{c}\text { Ratio } \\
(17) /(16)\end{array}$ & $\begin{array}{c}\text { Ratio } \\
(18) /(17)\end{array}$ & $\begin{array}{l}\text { Degree } \\
\text { (20) }\end{array}$ & $\begin{array}{c}\text { Graduate } \\
\text { (21) }\end{array}$ & $\begin{array}{c}\text { High School } \\
\text { (22) }\end{array}$ & $\begin{array}{c}\text { Ratio } \\
(21) /(20)\end{array}$ & $\begin{array}{c}\text { Ratio } \\
(22) /(21)\end{array}$ \\
\hline 1975 & 31155 & 36731 & 51379 & 1.18 & 1.40 & 31175 & 36799 & 51546 & 1.18 & 1.40 \\
\hline 1976 & 31899 & 36864 & 52125 & 1.16 & 1.41 & 31905 & 36840 & 52146 & 1.15 & 1.42 \\
\hline 1977 & 31429 & 37273 & 52151 & 1.19 & 1.40 & 31441 & 37224 & 51931 & 1.18 & 1.40 \\
\hline 1978 & 32226 & 37112 & 51642 & 1.15 & 1.39 & 32234 & 37175 & 51705 & 1.15 & 1.39 \\
\hline 1979 & 31956 & 36775 & 51513 & 1.15 & 1.40 & 31871 & 36736 & 51310 & 1.15 & 1.40 \\
\hline 1980 & 30218 & 35458 & 48448 & 1.17 & 1.37 & 30265 & 35519 & 49366 & 1.17 & 1.39 \\
\hline 1981 & 29441 & 34645 & 48855 & 1.18 & 1.41 & 29449 & 34644 & 48853 & 1.18 & 1.41 \\
\hline 1982 & 28280 & 34430 & 48928 & 1.22 & 1.42 & 28280 & 34435 & 48999 & 1.22 & 1.42 \\
\hline 1983 & 28964 & 33881 & 48984 & 1.17 & 1.45 & 28963 & 33875 & 48989 & 1.17 & 1.45 \\
\hline 1984 & 28875 & 34731 & 49222 & 1.20 & 1.42 & 28875 & 34731 & 49222 & 1.20 & 1.42 \\
\hline 1985 & 28723 & 34771 & 50486 & 1.21 & 1.45 & 28796 & 34795 & 51019 & 1.21 & 1.47 \\
\hline 1986 & 29133 & 35538 & 52751 & 1.22 & 1.48 & 29130 & 35521 & 52765 & 1.22 & 1.49 \\
\hline 1987 & 30046 & 35755 & 52937 & 1.19 & 1.48 & 30127 & 35725 & 52986 & 1.19 & 1.48 \\
\hline 1988 & 29218 & 35845 & 52947 & 1.23 & 1.48 & 29148 & 35869 & 52990 & 1.23 & 1.48 \\
\hline 1989 & 28475 & 36083 & 54522 & 1.27 & 1.51 & 28443 & 36085 & 54577 & 1.27 & 1.51 \\
\hline 1990 & 27533 & 34652 & 52953 & 1.26 & 1.53 & 27573 & 34664 & 52982 & 1.26 & 1.53 \\
\hline 1991 & 26985 & 34054 & 52256 & 1.26 & 1.53 & 27195 & 33984 & 52296 & 1.25 & 1.54 \\
\hline 1992 & 26795 & 34127 & 52684 & 1.27 & 1.54 & 26855 & 34150 & 52678 & 1.27 & 1.54 \\
\hline 1993 & 26163 & 34408 & 54988 & 1.32 & 1.60 & 26717 & 34795 & 54704 & 1.30 & 1.57 \\
\hline 1994 & 26642 & 34935 & 55723 & 1.31 & 1.60 & 26432 & 35037 & 55730 & 1.33 & 1.59 \\
\hline 1995 & 26736 & 35375 & 55261 & 1.32 & 1.56 & 26789 & 35617 & 55113 & 1.33 & 1.55 \\
\hline 1996 & 27120 & 36037 & 56642 & 1.33 & 1.57 & 27296 & 36009 & 56649 & 1.32 & 1.57 \\
\hline 1997 & 29063 & 35722 & 57405 & 1.23 & 1.61 & 29113 & 35707 & 57399 & 1.23 & 1.61 \\
\hline 1998 & 27207 & 36001 & 59051 & 1.32 & 1.64 & 27524 & 35886 & 59077 & 1.30 & 1.65 \\
\hline 1999 & 27048 & 36713 & 60118 & 1.36 & 1.64 & 27174 & 36693 & 60136 & 1.35 & 1.64 \\
\hline 2000 & 27744 & 37238 & 61404 & 1.34 & 1.65 & 28380 & 37383 & 61347 & 1.32 & 1.64 \\
\hline 2001 & 28264 & 37227 & 62361 & 1.32 & 1.68 & 29253 & 37505 & 62085 & 1.28 & 1.66 \\
\hline 2002 & 27864 & 37318 & 61984 & 1.34 & 1.66 & 28157 & 37341 & 61940 & 1.33 & 1.66 \\
\hline 2003 & 27858 & 37481 & 61527 & 1.35 & 1.64 & 27660 & 37362 & 61649 & 1.35 & 1.65 \\
\hline 2004 & 26757 & 37118 & 61331 & 1.39 & 1.65 & 27241 & 37274 & 61135 & 1.37 & 1.64 \\
\hline 2005 & 26944 & 36731 & 61567 & 1.36 & 1.68 & & & & & \\
\hline 2006 & 27493 & 36589 & 61830 & 1.33 & 1.69 & & & & & \\
\hline
\end{tabular}

Source: Author's calculations using public and internal March CPS data. 
Figure 1: Trend in the female-male earnings ratio 1975-1992 (1975 normalized to 1)

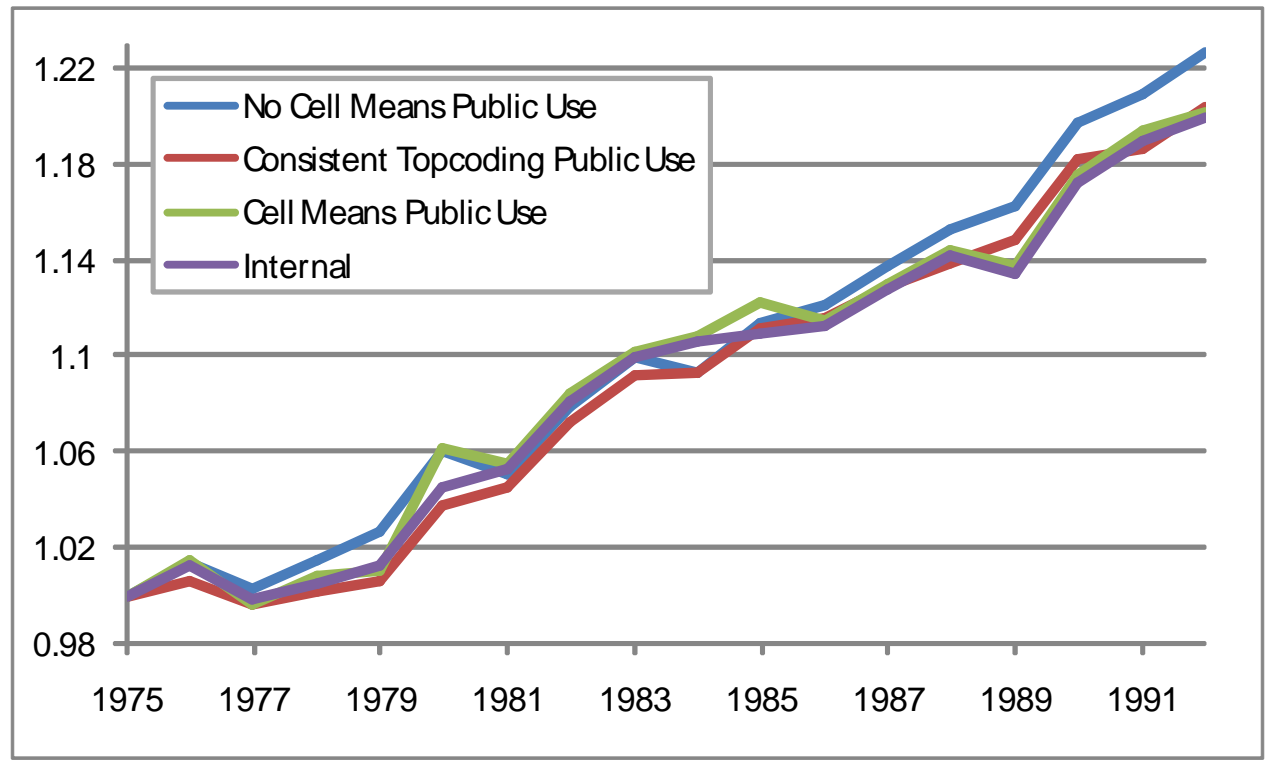

Figure 2: Trend in the female-male earnings ratio 1993-2006 (1993 normalized to 1)

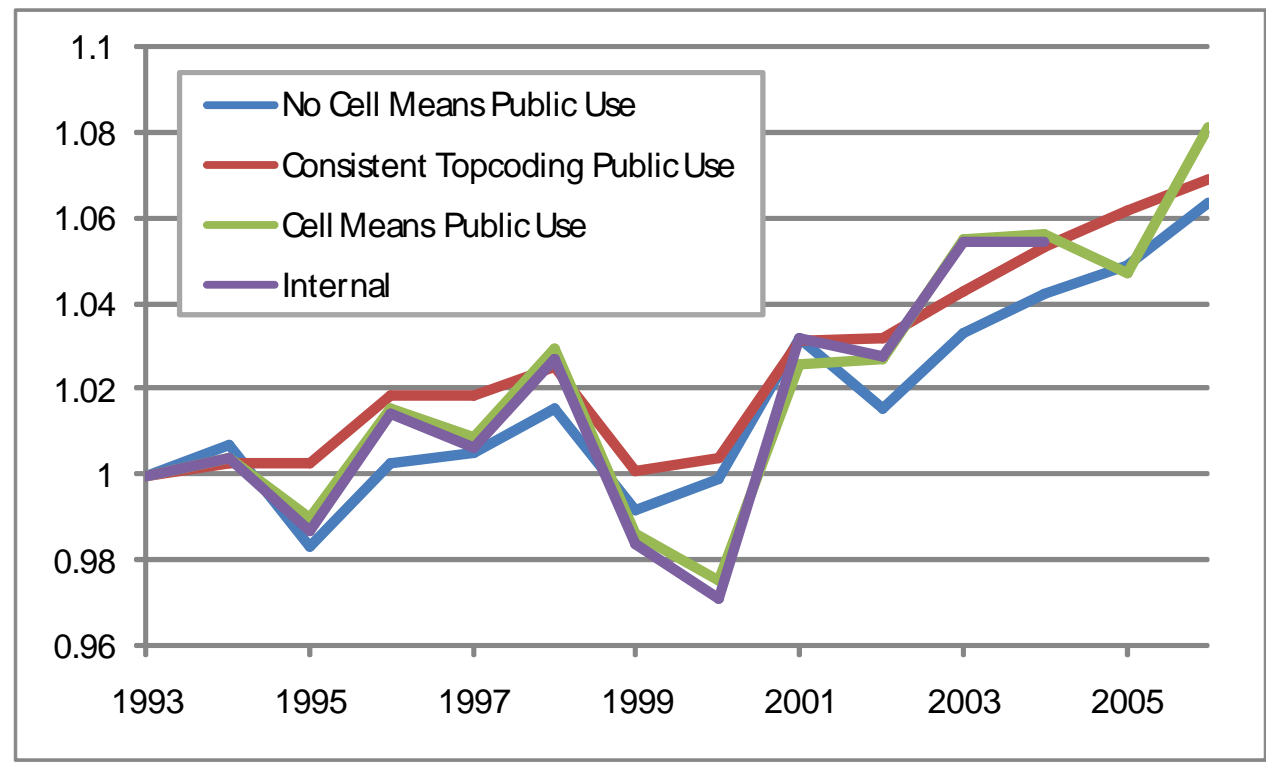


Figure 3: Trend in the black-white earnings ratio 1975-1992 (1975 normalized to 1)

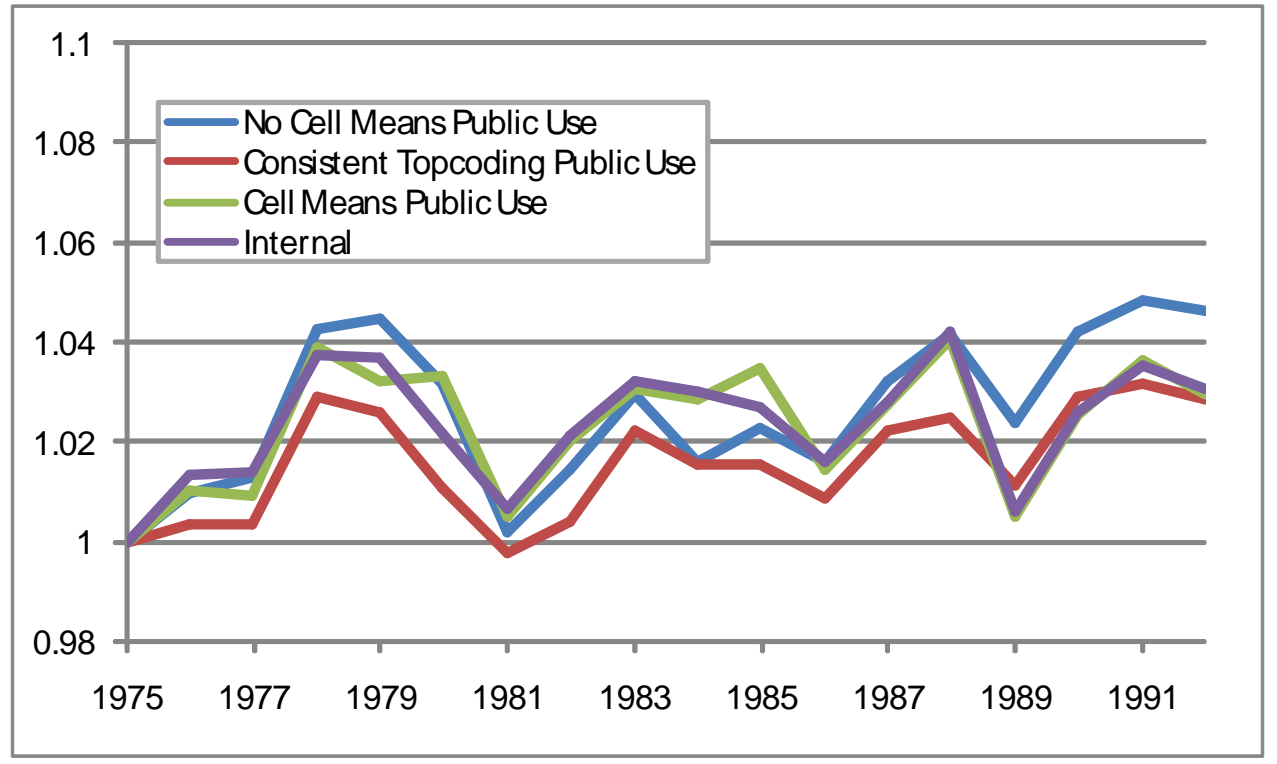

Figure 4: Trend in the black-white earnings ratio 1993-2006 (1993 normalized to 1)

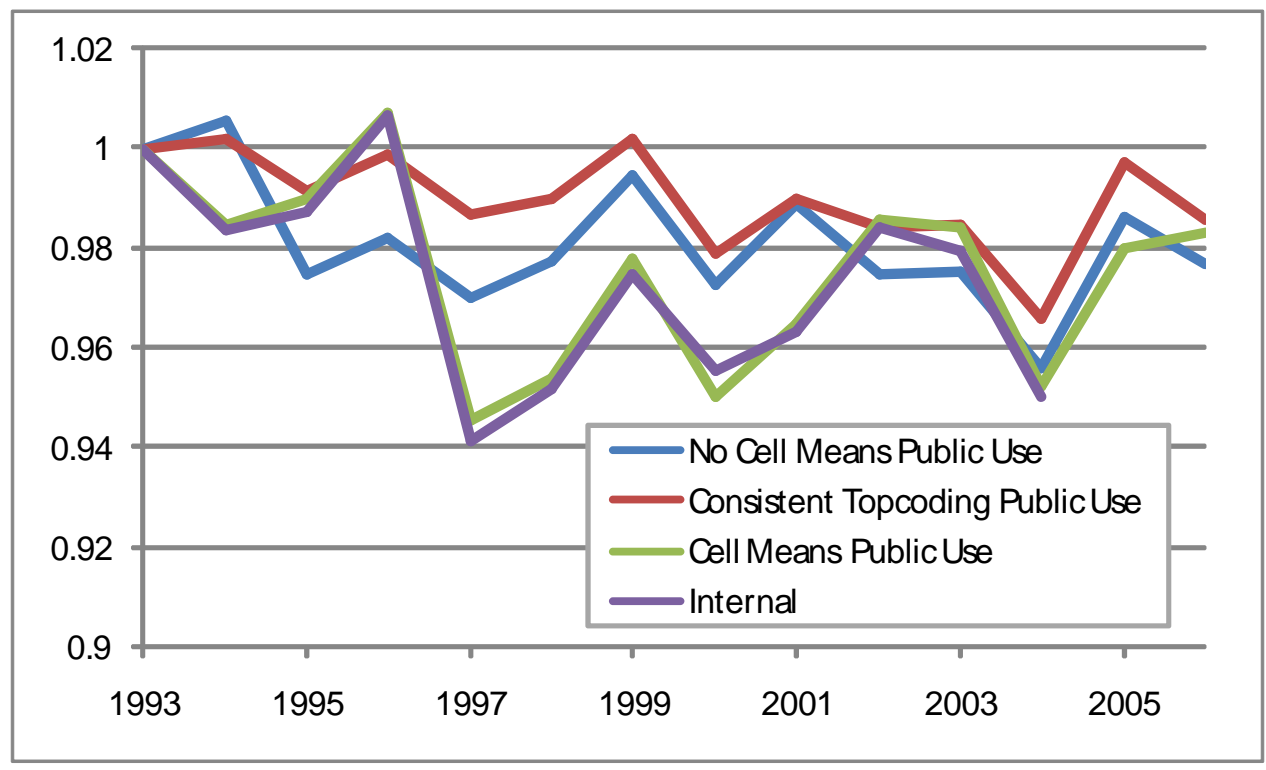


Figure 5: Trend in the earnings ratio between workers with post-secondary education and workers with only a high-school degree 1975-1992 (1975 normalized to 1)

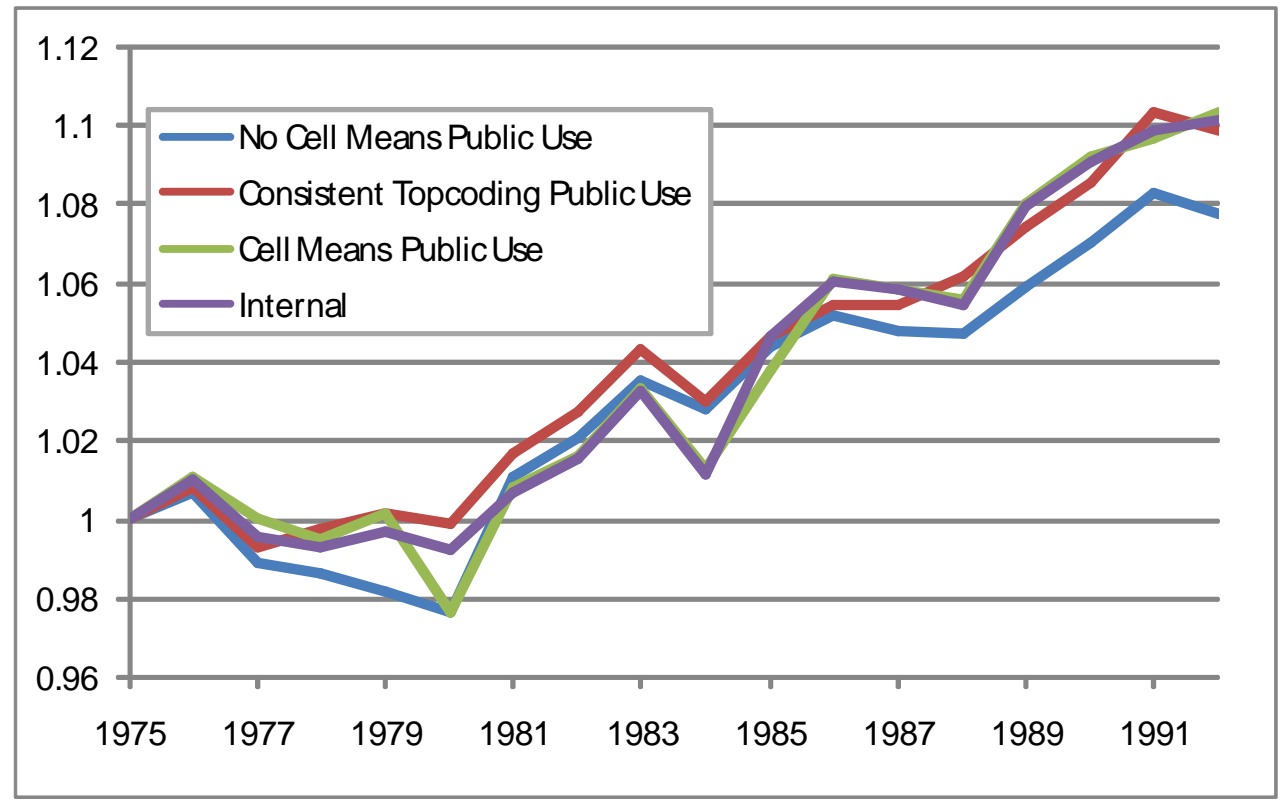

Figure 6: Trend in the earnings ratio between workers with post-secondary education and workers with only a high-school degree 1993-2006 (1993 normalized to 1)

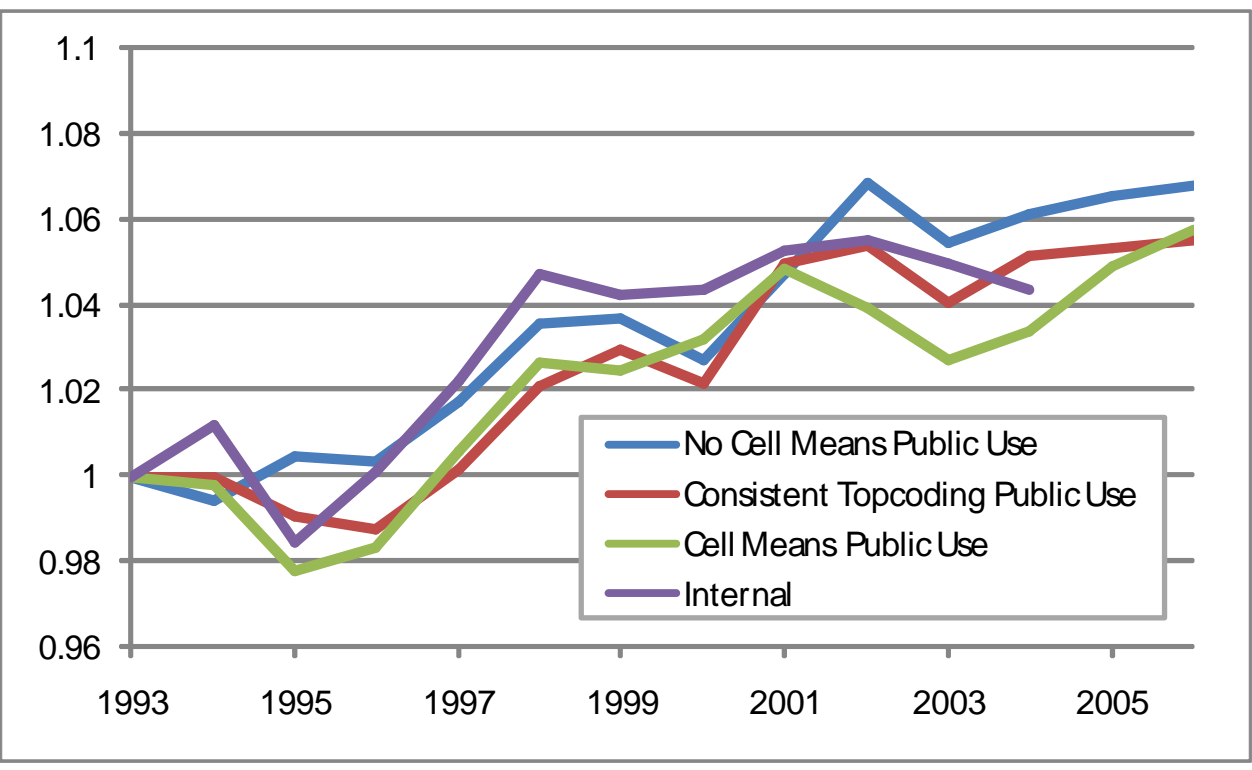




\section{Appendix Table 1. Labor Earnings Items Reported in the Current Population Survey}

\begin{tabular}{|c|c|c|c|}
\hline Name & $\begin{array}{c}\text { Name in } \\
\text { Public Files }\end{array}$ & $\begin{array}{c}\text { Name in } \\
\text { Internal Files } \\
\end{array}$ & Definition \\
\hline \multicolumn{4}{|c|}{$1976-1987$} \\
\hline Wages & I51A & WSAL_VAL & Wages and Salaries \\
\hline Self Employment & I51B & SEMP_VAL & Self employment income \\
\hline Farm & I51C & FRSE_VAL & Farm income \\
\hline \multicolumn{4}{|c|}{ 1988-2007 } \\
\hline Primary earnings & ERN_VAL & ERN_VAL & Primary Earnings \\
\hline Wages & WS_VAL & WS_VAL & Wages and Salaries - Second Source \\
\hline Self Employment & SE_VAL & SE_VAL & Self employment income - Second Source \\
\hline Farm & FRM_VAL & FRM_VAL & Farm income - Second Source \\
\hline
\end{tabular}




\section{Appendix Table 2: Public and Internal Topcoding Points for each Labor Earnings Source in Dollars (1975-1986)}

Public-Use Data Topcode

\begin{tabular}{cccccccc} 
& \multicolumn{3}{c}{ Thresholds } & & \multicolumn{3}{c}{ Internal Data Topcode Thresholds } \\
\cline { 2 - 3 } \cline { 7 - 8 } Income & Wages & $\begin{array}{c}\text { Self } \\
\text { Employment }\end{array}$ & Farm & & Wages & $\begin{array}{c}\text { Self } \\
\text { Employment }\end{array}$ & Farm \\
Year & (I51A) & (I51B) & $($ I51C) & & (I51A) & (I51B) & (I51C) \\
1975 & 50,000 & 50,000 & 50,000 & & 99,999 & 99,999 & 99,999 \\
1976 & 50,000 & 50,000 & 50,000 & & 99,999 & 99,999 & 99,999 \\
1977 & 50,000 & 50,000 & 50,000 & & 99,999 & 99,999 & 99,999 \\
1978 & 50,000 & 50,000 & 50,000 & & 99,999 & 99,999 & 99,999 \\
1979 & 50,000 & 50,000 & 50,000 & & 99,999 & 99,999 & 99,999 \\
1980 & 50,000 & 50,000 & 50,000 & & 99,999 & 99,999 & 99,999 \\
1981 & 75,000 & 75,000 & 75,000 & & 99,999 & 99,999 & 99,999 \\
1982 & 75,000 & 75,000 & 75,000 & & 99,999 & 99,999 & 99,999 \\
1983 & 75,000 & 75,000 & 75,000 & & 99,999 & 99,999 & 99,999 \\
1984 & 99,999 & 99,999 & 99,999 & & 99,999 & 99,999 & 99,999 \\
1985 & 99,999 & 99,999 & 99,999 & & 250,000 & 250,000 & 250,000 \\
1986 & 99,999 & 99,999 & 99,999 & & 250,000 & 250,000 & 250,000
\end{tabular}

Source: Public Use Topcode points from Current Population Survey Annual Demographic File Technical Documentation (1976-1987) and Current Population Survey Annual Social and Economic Supplement Technical Documentation (2003-2007). Internal Topcode points from Author's calculations using internal March CPS data 


\section{Appendix Table 3: Public and Internal Topcoding Points for each Labor Earnings Source in Dollars (1987-2006)}

\begin{tabular}{|c|c|c|c|c|c|c|c|c|}
\hline \multirow{3}{*}{$\begin{array}{c}\text { Income } \\
\text { Year }\end{array}$} & \multicolumn{4}{|c|}{ Public-Use Data Topcode Thresholds } & \multicolumn{4}{|c|}{ Internal Data Topcode Thresholds } \\
\hline & Primary & & Self & & Primary & & Self & \\
\hline & $\begin{array}{c}\text { Earnings } \\
\text { (ERN_VAL) }\end{array}$ & $\begin{array}{c}\text { Wages } \\
\text { (WS_VAL) }\end{array}$ & $\begin{array}{c}\text { Employment } \\
\text { (SE_VAL) }\end{array}$ & $\begin{array}{c}\text { Farm } \\
\text { (FRM_VAL) }\end{array}$ & $\begin{array}{c}\text { Earnings } \\
\text { (ERN_VAL) }\end{array}$ & $\begin{array}{c}\text { Wages } \\
\text { (WS_VAL) }\end{array}$ & $\begin{array}{c}\text { Employment } \\
\text { (SE_VAL) }\end{array}$ & $\begin{array}{c}\text { Farm } \\
(\text { FRM_VAL) }\end{array}$ \\
\hline 1988 & 99,999 & 99,999 & 99,999 & 99,999 & 299,999 & 99,999 & 99,999 & 99,999 \\
\hline 1989 & 99,999 & 99,999 & 99,999 & 99,999 & 299,999 & 99,999 & 99,999 & 99,999 \\
\hline 1990 & 99,999 & 99,999 & 99,999 & 99,999 & 299,999 & 99,999 & 99,999 & 99,999 \\
\hline 1991 & 99,999 & 99,999 & 99,999 & 99,999 & 299,999 & 99,999 & 99,999 & 99,999 \\
\hline 1992 & 99,999 & 99,999 & 99,999 & 99,999 & 299,999 & 99,999 & 99,999 & 99,999 \\
\hline 1993 & 99,999 & 99,999 & 99,999 & 99,999 & 299,999 & 99,999 & 99,999 & 99,999 \\
\hline 1994 & 99,999 & 99,999 & 99,999 & 99,999 & 999,999 & 999,999 & 999,999 & 999,999 \\
\hline 1995 & 99,999 & 99,999 & 99,999 & 99,999 & 1,099,999 & 1,099,999 & 999,999 & 999,999 \\
\hline 1996 & 150,000 & 25,000 & 40,000 & 25,000 & 1,099,999 & 1,099,999 & 999,999 & 999,999 \\
\hline 1997 & 150,000 & 25,000 & 40,000 & 25,000 & $1,099,999$ & 1,099,999 & 999,999 & 999,999 \\
\hline 1998 & 150,000 & 25,000 & 40,000 & 25,000 & $1,099,999$ & $1,099,999$ & 999,999 & 999,999 \\
\hline 1999 & 150,000 & 25,000 & 40,000 & 25,000 & 1,099,999 & 1,099,999 & 999,999 & 999,999 \\
\hline 2000 & 150,000 & 25,000 & 40,000 & 25,000 & $1,099,999$ & $1,099,999$ & 999,999 & 999,999 \\
\hline 2001 & 150,000 & 25,000 & 40,000 & 25,000 & $1,099,999$ & $1,099,999$ & 999,999 & 999,999 \\
\hline 2002 & 150,000 & 25,000 & 40,000 & 25,000 & $1,099,999$ & 1,099,999 & 999,999 & 999,999 \\
\hline 2003 & 200,000 & 35,000 & 50,000 & 25,000 & 1,099,999 & 1,099,999 & 999,999 & 999,999 \\
\hline 2004 & 200,000 & 35,000 & 50,000 & 25,000 & 1,099,999 & 1,099,999 & 999,999 & 999,999 \\
\hline 2005 & 200,000 & 35,000 & 50,000 & 25,000 & $1,099,999$ & 1,099,999 & 999,999 & 999,999 \\
\hline 2006 & 200,000 & 35,000 & 50,000 & 25,000 & & & & \\
\hline 2007 & 200,000 & 35,000 & 50,000 & 25,000 & & & & \\
\hline
\end{tabular}

Source: Public Use Topcode points from Current Population Survey Annual Demographic File Technical Documentation (1988-2002) and Current Population Survey Annual Social and Economic Supplement Technical Documentation (2003-2007). Internal Topcode points from Author's calculations using internal March CPS data 